\title{
Development and Validation of a Capillary Electrophoresis Method for the Determination of Sulfate in Indinavir Sulfate Raw Material
}

\author{
Elisabete A. Pereira, ${ }^{*}$ Gustavo A. Micke and Marina F. M. Tavares \\ Instituto de Química, Universidade de São Paulo, CP 26077, 05513-970 São Paulo - SP, Brazil
}

\begin{abstract}
O presente trabalho descreve um método simples e rápido por eletroforese capilar, utilizando detecção indireta $(230 \mathrm{~nm})$ para determinação quantitativa de sulfato em sulfato de indinavir (matéria-prima). Uma solução contendo $10 \mathrm{mmol} \mathrm{L}^{-1}$ de molibdato de amônio e $0,15 \mathrm{mmol}$ $\mathrm{L}^{-1}$ de brometo de cetiltrimetilamônio $(\mathrm{pH} 7,5)$ foi utilizada como eletrólito de corrida. As amostras foram injetadas hidrodinamicamente com pressão $5000 \mathrm{~Pa}$ durante $3 \mathrm{~s}$. A resposta foi linear no intervalo entre $10,1 \mu \mathrm{g} \mathrm{mL}^{-1}$ a $79,8 \mu \mathrm{g} \mathrm{mL} \mathrm{m}^{-1}$. Os limites de detecção e quantificação foram de 0,34 e $1,13 \mu \mathrm{g} \mathrm{mL}{ }^{-1}$, respectivamente. A precisão intra-dia, determinada como desvio padrão relativo, foi de $2,8 \%$ para dez preparações independentes da amostra. Os valores de recuperação para três diferentes níveis de concentração variaram de 96,9 a 102,4\%. A metodologia foi aplicada a amostras reais. A concentração de sulfato na amostra variou de 13,3 a 13,5\% ( $\mathrm{m} / \mathrm{m}$, calculado com relação ao material seco).
\end{abstract}

In this work, a simple and fast capillary electrophoresis method using indirect UV detection $(230 \mathrm{~nm})$ for the quantitative determination of sulfate in the indinavir sulfate raw material was described. A running electrolyte consisting of $10 \mathrm{mmol} \mathrm{L}^{-1}$ ammonium molybdate containing $0.15 \mathrm{mmol} \mathrm{L}^{-1}$ cetyltrimethylammonium bromide $(\mathrm{pH} 7.5)$ was used. Samples were injected hydrodynamically by applying $5000 \mathrm{~Pa}$ pressure during $3 \mathrm{~s}$. The response was linear from $10.1 \mu \mathrm{g} \mathrm{mL} L^{-1}$ to $79.8 \mu \mathrm{g} \mathrm{mL}^{-1}$. Limits of detection and quantification were 0.34 and $1.13 \mu \mathrm{g}$ $\mathrm{mL}^{-1}$, respectively. The intra-day precision expressed as relative standard deviation was $2.8 \%$ for 10 independent sample preparations. Recoveries varying from 96.9 to $102.4 \%$ at three concentration levels were obtained. The methodology was successfully applied for real samples. The concentration of sulfate in indinavir sulfate raw material varied from 13.3 to $13.5 \%(\mathrm{~m} / \mathrm{m}$ calculated as anhydrous base).

Keywords: indinavir sulfate, capillary electrophoresis, sulfate, validation, HIV

\section{Introduction}

Indinavir sulfate was approved by the FDA (Food and Drugs Administration) on March 13, 1996, for use in combination with other protease inhibitors, nucleoside analogues or reverse transcriptase inhibitors for the treatment against acquired immune deficiency syndrome (AIDS). ${ }^{1}$ Indinavir is prescribed as a sulfate salt due to superior gastrointestinal solubility and absorption when compared with the free base. ${ }^{2}$

When drugs are manufactured as salts, an analytical technique is required to confirm that correct levels of counter ion are present. ${ }^{3}$ The counter ions of drugs with ionic groups are of importance because the physicochemical properties, stability and bioavailability of the

* e-mail: ealves@iq.usp.br drugs depend on their salt forms. An analytical technique such as ion chromatography (IC) and titrimetry is often used for the analysis of counter ion in pharmaceutical drug substances. ${ }^{3}$ However, these methods are laborious and time consuming, besides the high maintenance cost of IC technique.

Capillary electrophoresis (CE) has been successfully applied to the analysis of a variety of anionic solutes in several complex samples. ${ }^{4} \mathrm{CE}$ has shown to be a powerful analytical tool for the determination of ions in the various segments of chemical, pharmaceutical and food industry, as well as in the characterization of samples of clinical and environmental interest. ${ }^{5-9}$ Various metal, inorganic, and organic counter ions have been determined by $\mathrm{CE}$ in pharmaceutical formulation. ${ }^{10-13}$ This work describes the first report of a $\mathrm{CE}$ validated method for quantitative determination of sulfate in indinavir sulfate raw material. 


\section{Experimental}

\section{Reagents and solutions}

All reagents were of analytical grade and used with no further purification. Potassium sulfate and sodium salts of chloride, nitrate, perchlorate (internal standard), carbonate and cetyltrimethylammonium bromide (CTAB) were obtained from Aldrich/Sigma (St. Louis, MO, USA). Ammonium molybdate was obtained from Dinâmica (São Paulo, Brazil). Indinavir sulfate raw material was kindly donated by the Instituto de Tecnologia de Fármacos Fundação Oswaldo Cruz (Rio de Janeiro, Brazil).

Stock solutions of chloride, nitrate and carbonate (1000 $\left.\mu \mathrm{g} \mathrm{mL}^{-1}\right)$, sulfate $\left(844.0 \mu \mathrm{g} \mathrm{mL}^{-1}\right)$, perchlorate (5000 $\left.\mu \mathrm{g} \mathrm{mL}^{-1}\right)$ and indinavir sulfate $\left(269.9 \mu \mathrm{g} \mathrm{mL}^{-1}\right.$ of sulfate ion) were prepared in deionized water. Working standard solutions were prepared fresh daily by diluting appropriately the stock solutions with deionized water.

\section{Calibration curve}

Appropriate aliquots of the standard stock solutions of sulfate and a fixed aliquot of perchlorate (internal standard) were transferred into separate $10 \mathrm{~mL}$ volumetric flasks. The volume was completed with deionized water. Concentration range from 10.1 to $79.8 \mu \mathrm{g} \mathrm{mL}^{-1}$ of sulfate, and $20 \mu \mathrm{g} \mathrm{mL}^{-1}$ of perchlorate were obtained.

\section{Accuracy}

To determine the method accuracy, recovery tests were performed according to procedures endorsed by AOAC. ${ }^{14}$ Commercial raw material solution was spiked with known quantities of sulfate standard solution and analyzed by the proposed method, according to the procedure depicted in Table 1.

\section{Apparatus}

All experiments were conducted in a capillary electrophoresis system (Agilent Technologies, model HP
3D CE, Palo Alto, CA, USA), equipped with a diode array detector, temperature control device maintained at $29^{\circ} \mathrm{C}$ and data acquisition and treatment software (HP ChemStation, rev A.06.01). Fused-silica capillaries (Polymicro Technologies, Phoenix, AZ, USA) with dimensions $48.5 \mathrm{~cm}$ total length (40 cm effective length) and $75 \mu \mathrm{m}$ i.d. x $375 \mu \mathrm{m}$ o.d. were used. Samples were injected hydrodynamically, with a $5000 \mathrm{~Pa}$ for $3 \mathrm{~s}$ and detected indirectly at $230 \mathrm{~nm}$. The applied voltage was set at $-10 \mathrm{kV}$. At the beginning of each day, the fusedsilica capillary was conditioned by flushing $1 \mathrm{~mol} \mathrm{~L}^{-1}$ $\mathrm{NaOH}$ solution $(5 \mathrm{~min}$ ), followed by a $5 \mathrm{~min}$ flush of deionized water and electrolyte solution (40 min). Before each run, the capillary was just rinsed with fresh electrolyte solution (3 $\mathrm{min})$.

\section{Results and Discussion}

Since most inorganic anions have low or no absorbance in the UV-Vis range of the spectrum, the indirect UV detection is often employed in their determination. This technique uses a UV-absorbing ion, known as the probe ion, in the background electrolyte. Displacement of the probe ion by a migrating sample anion results in a quantifiable decrease in the background absorbance. ${ }^{4}$ In this work, molybdate was selected as the electrolyte anion because its mobility is similar to the mobility of the analytes of interest, it presents high molar absorptivity $\left(5,650 \mathrm{~cm}^{-1} \mathrm{~L} \mathrm{~mol}^{-1}\right)$ and its solutions are stable upon storage and continuous analysis. ${ }^{15}$

The separation mechanism in $\mathrm{CE}$ is based on differences between the electrophoretic mobilities of charged species in the presence of an electric field. In a conventional CE system the electroosmotic flow (EOF) is towards the cathode, anions with an electrophoretic mobility higher than the electroosmotic mobility of the bulk electrolyte cannot reach the detector and the polarity of the potential applied must be reversed in order to detect these anions. However, under these conditions anions with mobilities lower than electroosmotic mobility would never reach the detector. Therefore, for most anion separations it is necessary to use a modifier to reverse the direction of

Table 1. Procedure for the recovery study (standard solution of sulfate added to indinavir sulfate raw material solution)

\begin{tabular}{cccc}
\hline $\begin{array}{c}\text { Commercial sample } \\
\text { solution }^{\mathrm{a}}\left(269.9 \mu \mathrm{g} \mathrm{mL} \mathrm{mL}^{-1}\right)\end{array}$ & $\begin{array}{c}\text { Sulfate standard } \\
\text { solution }\left(844.0 \mu \mathrm{g} \mathrm{mL}^{-1}\right)\end{array}$ & $\begin{array}{c}\text { Internal standard } \\
\left(5000 \mu \mathrm{g} \mathrm{mL}^{-1}\right)\end{array}$ & $\begin{array}{c}\text { Final concentration } \\
\left(\mu \mathrm{g} \mathrm{mL} \mathrm{m}^{-1}\right)\end{array}$ \\
\hline 500 & Aliquots $(\mu \mathrm{L})^{\mathrm{b}}$ & 40.0 & 13.5 \\
500 & -120 & 40.0 & 26.6 \\
500 & 240 & 40.0 & 33.7 \\
500 & 350 & 40.0 & 20.0 \\
\hline
\end{tabular}

a Solution of indinavir sulfate raw material; ${ }^{\text {b }}$ To $10 \mathrm{~mL}$ volumetric flasks; ${ }^{\mathrm{c}}$ Internal standard: perchlorate. 
the EOF. ${ }^{4}$ Alternatively, rapid and highly efficient separation of anions can be achieved by CE in the absence of any flow modifier using the short-end injection technique. ${ }^{16-18}$

In order to obtain the best separation of the anions, i.e., short analysis time and good resolution, both separation modes, with and without flow reversal, were studied in this work using a molybdate solution as electrolyte.

\section{Separation of inorganic anions without flow reversal}

The $\mathrm{pH}$ is an important parameter in CE separations when fused-silica capillaries are used because it governs the EOF. The $\mathrm{pH}$ also governs the ionization of weak acids or bases, but for most inorganic anions this effect is not important because they are totally ionized in the operational $\mathrm{pH}$ interval of CE separations ( $\mathrm{pH} 2-10)$. In order to keep the migration time of anions reasonably short without flow reversal, the $\mathrm{pH}$ was adjusted to 5.0, with acetic acid, and $\mathrm{CE}$ runs were performed with the use of short-end injection (effective capillary length $8.5 \mathrm{~cm}$ ).

Initially, to evaluate the separation of the chloride, sulfate, nitrate, perchlorate and carbonate, a $5 \mathrm{mmol}$ $\mathrm{L}^{-1}$ molybdate solution was used as electrolyte. Additionally, for sample introduction two injection modes, the hydrodynamic and electrokinetic sampling, were also tested. Figure 1 shows the electropherograms obtained. Under both injection conditions, all the compounds studied were separated in less than $3 \mathrm{~min}$ but electrokinetic injection was superior with respect to sensitivity and efficiency. However, both injection modes provided poor repeatability ( $>2 \% \mathrm{RSD}, \mathrm{n}=10$ ) for migration time and peak area. This behavior might be associated with the equipment design. The end part of the capillary is not inside the thermostatted cassette and in this set up, heat which dissipates through the capillary walls may not be removed so efficiently. As a consequence, the precision may be poor because of the lack of temperature control.

\section{Separation of inorganic anions with flow reversal}

Reversal of the EOF is achieved by the addition of a cationic surfactant, such as CTAB to the electrolyte. Initial conditions were based on the literature. ${ }^{15}$ In the work of Fung and Lau, the separation of organic and inorganic anions in rain water was conducted using a electrolyte containing $5 \mathrm{mmol} \mathrm{L}^{-1}$ molybdate, $0.15 \mathrm{mmol} \mathrm{L}^{-1}$ cetyltrimethylammoniun hydroxide $(\mathrm{CTAH}), 0.01 \%$
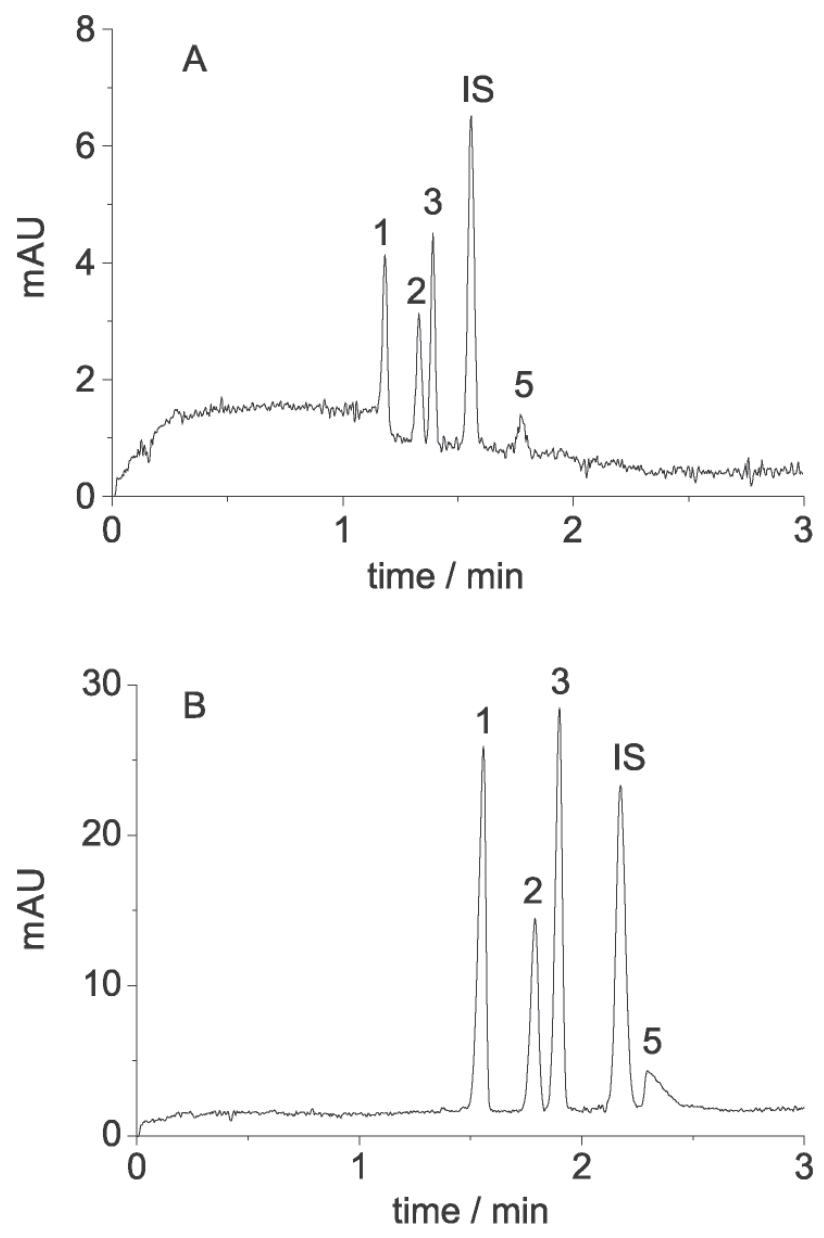

Figure 1. Electropherograms of a standard solution of the inorganic anions without flow reversal. Concentration of each anion standard: $5.0 \mu \mathrm{g} \mathrm{mL}^{-1}$. Separation conditions: fused silica capillary, $75 \mu \mathrm{m}$ i.d., $375 \mu \mathrm{m}$ o.d., $48.5 \mathrm{~cm}$ total length (effective capillary length $8.5 \mathrm{~cm}$ ); electrolyte: $5 \mathrm{mmol} \mathrm{L}^{-1}$ molybdate, $\mathrm{pH} 5.0$, voltage: $10 \mathrm{kV}$; temperature: $25{ }^{\circ} \mathrm{C}$; indirect UV detection at $230 \mathrm{~nm}$. (A) hydrodynamic injection: $5 \mathrm{~s} x-5000 \mathrm{~Pa}$; (B) eletrokinetic injection: $3 \mathrm{~s}$ x $2.5 \mathrm{kV}$. Peak identification: 1. Chloride; 2. Sulfate 3. Nitrate; 4. Perchlorate (IS); 5. Carbonate.

(m/v) polyvinil alcohol (PVA) and $5 \mathrm{mmol} \mathrm{L}^{-1}$ Tris buffer, $\mathrm{pH}$ 7.9. Since the methodology parameters seemed to have been optimized according to the sample nature, it was decided to explore in better detail the buffer composition. The influence of the molybdate concentration was studied in the interval $5-20 \mathrm{mmol} \mathrm{L}^{-1}$ in electrolytes with a fixed amount of CTAB $\left(0.15 \mathrm{mmol} \mathrm{L}^{-1}\right)$. When the molybdate concentration was increased, a substantial gain in resolution of chloride and sulfate was achieved (not shown). However, concentrations above $10 \mathrm{mmol} \mathrm{L}^{-1}$ produced loss of resolution between sulfate and nitrate peaks (not shown). Moreover, the Joule heating effect is also increased rapidly at higher molybdate concentration, leading to baseline noise. Therefore in this study, $10 \mathrm{mmol} \mathrm{L}^{-1}$ molybdate was chosen as the optimum concentration. 
Buffered solutions tend to be used in CE to limit the possible changes in the composition of the electrolyte and to deliver results with better reproducibility. ${ }^{19}$ In the case of anion separations, buffering using counter ion, such as Tris, is a useful option. However, when $5 \mathrm{mmol} \mathrm{L}^{-1}$ Tris buffer was added to the molybdate electrolyte baseline oscillations were observed. In order to provide stabilization against $\mathrm{pH}$ change, when unbuffered molybdate elecrolyte was used, electrolyte reservoirs were replenished each five runs.

In Figure 2, a typical electropherogram of a standard mixture is given, showing the separation of five anions at optimized conditions, i.e. unbuffered molybdate solution containing a flow modifier.

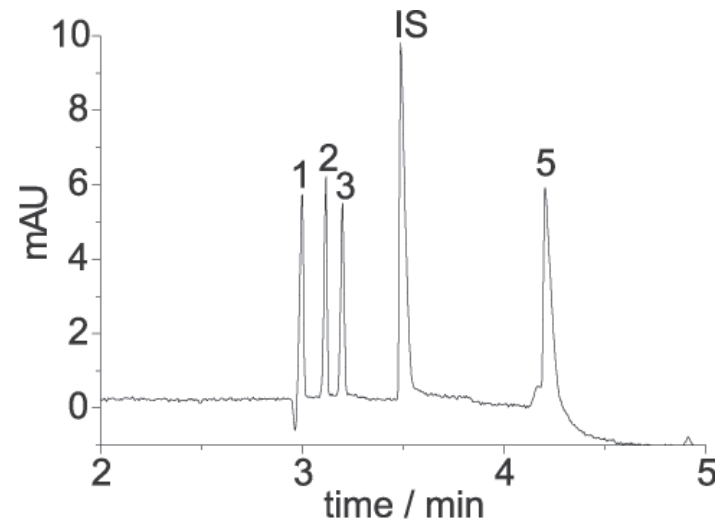

Figure 2. Electropherogram of a standard solution of the inorganic anions with flow reversal. Concentration of each anion standard: chloride, sulfate and nitrate $10 \mu \mathrm{g} \mathrm{mL}^{-1}$, perchlorate and carbonate $20 \mu \mathrm{g} \mathrm{mL}^{-1}$. Separation conditions: fused silica capillary, $75 \mu \mathrm{m}$ i.d., $375 \mu \mathrm{m}$ o.d., $48.5 \mathrm{~cm}$ total length ( $40 \mathrm{~cm}$ to detector); electrolyte: $10 \mathrm{mmol} \mathrm{L}^{-1}$ molybdate and $0.15 \mathrm{mmol} \mathrm{L}^{-1} \mathrm{CTAB}$; voltage: $-10 \mathrm{kV}$; hydrodynamic injection: 3 s x $5000 \mathrm{~Pa}$; indirect UV absorbance detection at $230 \mathrm{~nm}$; temperature: $29^{\circ}$ C. 1. Chloride; 2. Sulfate 3. Nitrate; 4. Perchlorate (IS); 5. Carbonate.

\section{Method validation}

The proposed CE methodology was validated by determining its performance characteristics regarding specificity, linearity, limit of detection, limit of quantification, precision and accuracy. ${ }^{20,21}$

\section{Precision}

Precision is the measure of the degree of repeatability of an analytical method under normal operation and is normally expressed as the percent relative standard deviation (RSD) for a statistically significant number of samples. ${ }^{20}$ The precision of the proposed method regarding peak area and migration time repeatability for ten consecutive injections of the sulfate standard solution at $10 \mu \mathrm{g} \mathrm{mL}^{-1}$ was estimated. Since much of the variance in precision is attributable to variable injection volume, voltage or EOF, the incorporation of an appropriate internal standard (IS) is required to minimize these source errors. $^{22}$ It can be seen in Table 2 that the precision of injection for relative peak area (analyte/IS) was significantly improved from $8.0 \%$ RSD to $0.87 \%$.

Table 2. Analytical performance of the method regarding precision

\begin{tabular}{lccccc}
\hline Anion & $\begin{array}{c}\text { MT } \\
(\mathrm{min})\end{array}$ & $\begin{array}{c}\mathrm{MT}^{\mathrm{a}} \\
\mathrm{RSD}(\%)\end{array}$ & $\begin{array}{c}\mathrm{RMT}^{\mathrm{b}} \\
\mathrm{RSD}(\%)\end{array}$ & $\begin{array}{c}\mathrm{PA}^{\mathrm{c}} \\
\mathrm{RSD}(\%)\end{array}$ & $\begin{array}{c}\mathrm{RPA}^{\mathrm{d}} \\
\mathrm{RSD}(\%)\end{array}$ \\
\hline Sulfate & 3.2 & 0.27 & 0.13 & 8.0 & 0.87 \\
\hline
\end{tabular}

$\mathrm{RSD}=$ relative standard deviation (10 consecutive injections); ${ }^{\text {a }}$ Migration time; ${ }^{\mathrm{b}}$ Relative migration time (sulfate/IS); ${ }^{\mathrm{c}}$ Peak area; ${ }^{\mathrm{d}}$ Relative peak area (sulfate/IS).

The repeatability of sample preparation was also evaluated by preparing independently ten samples of indinavir sulfate raw material. Each solution was injected once and the average of relative peak area (sulfate/IS) was used for calculation. The intra-day precision expressed as RSD was $2.8 \%$.

\section{Specificity}

Specificity is described as the ability of a method to discriminate the analyte from all potential interfering substances. ${ }^{20,21}$ Inorganic anionic impurities as chloride, nitrate, and carbonate can derive from the manufacturing process of indinavir sulfate. The non-interference of chloride, nitrate and carbonate on the sulfate peak was assessed by injection the corresponding solutions (Figure 2). As it can be observed, none of these inorganic anions interfered in the analysis of sulfate, establishing therefore the method specificity.

\section{Linearity, limit of detection (LOD) and limit of quantification (LOQ)}

Linearity is the ability of the method to elicit test results that are directly proportional to analyte concentration within a given range. The specified range is normally derived from linearity studies and depend on the intended application of the procedure. ${ }^{21}$ Acceptable coefficients of correlation (0.99 or greater) and an intercept close to the origin should be achieved. ${ }^{21}$ For quantitative purposes, analytical curves based on relative peak area (sulfate/IS) versus concentration were built. The analytical curves consisted of five points and three replicate injections of standards at each concentration level were performed. As shown by the statistical data organized in Table 3 the method exhibited good linearity over the concentration range from $10.1 \mu \mathrm{g} \mathrm{mL}^{-1}$ to $79.8 \mu \mathrm{g} \mathrm{mL}^{-1}(\mathrm{r}=0.999)$. 
Table 3. Statistical parameters of the analytical curve and estimates of limits of detection (LOD) and quantification (LOQ) for the indirect UVabsorbance detection methodology

\begin{tabular}{ll}
\hline Parameter & Statistical data \\
\hline Concentration range ${ }^{\mathrm{a}}\left(\mu \mathrm{g} \mathrm{mL}^{-1}\right)$ & $10.1-79.8$ \\
Intercept & $0.06 \pm 0.04$ \\
Slope & $0.0401 \pm 0.0009$ \\
Coefficient of correlation $(\mathrm{r})$ & 0.999 \\
Limit of detection $\left(\mu \mathrm{g} \mathrm{mL}^{-1}\right)$ & 0.34 \\
Limit of quantification & $\left(\mu \mathrm{g} \mathrm{mL}^{-1}\right)$ \\
\hline
\end{tabular}

${ }^{a}$ Five data points, three replicate injection at each concentration level; ${ }^{b}$ $\mathrm{S} / \mathrm{N}=3 ;{ }^{\mathrm{c}} \mathrm{S} / \mathrm{N}=10$.

The limits of detection (LOD) and quantification (LOQ) for sulfate were 0.34 and $1.13 \mu \mathrm{g} \mathrm{mL}^{-1}$, respectively. The criterion used to determine the LOD and LOQ was based on signal-to-noise ratio $3: 1$ and 10:1, respectively. ${ }^{20,21}$

\section{Accuracy}

The accuracy express the closeness of agreement between the value found and the value that is accepted as a reference value. It is very common to evaluate accuracy by performing recovery experiments. ${ }^{20}$ The method accuracy was established by the recovery test of spiked commercial material samples. The results on the recoveries of sulfate added to indinavir sulfate raw material are given in Table 4, which shows that recoveries varying of 96.9 to $102.4 \%$ at three concentrations levels were obtained.

Table 4. Method validation regarding accuracy: recovery test

\begin{tabular}{cccc}
\hline $\begin{array}{l}\text { Indinavir sulfate } \\
\text { raw material }\end{array}$ & $\begin{array}{c}\text { Standard added } \\
\left(\mu \mathrm{g} \mathrm{mL}^{-1}\right)\end{array}$ & $\begin{array}{c}\text { Standard found } \\
\left(\mu \mathrm{g} \mathrm{mL}^{-1}\right)\end{array}$ & $\begin{array}{c}\text { Recovery } \\
(\%)\end{array}$ \\
\hline 1 & 10.1 & 9.8 & $96.9 \pm 0.4$ \\
1 & 20.2 & 19.6 & $97.1 \pm 0.6$ \\
1 & 29.5 & 30.2 & $102.4 \pm 0.5$ \\
\hline
\end{tabular}

1: commercial material.

\section{Application to real samples}

The method was applied for quantitative determination of sulfate ion in indinavir sulfate raw material. Three different sample weights were taken and each was analyzed in triplicate. A typical electropherogram for separation of sulfate in indinavir sulfate raw material is shown in Figure 3. The analytical results are summarized in Table 5. The concentrations of sulfate were in agreement with the specification range (13.3 to $14.4 \%$ calculated as anhydrous base) established by regulatory authorities. ${ }^{23,24}$

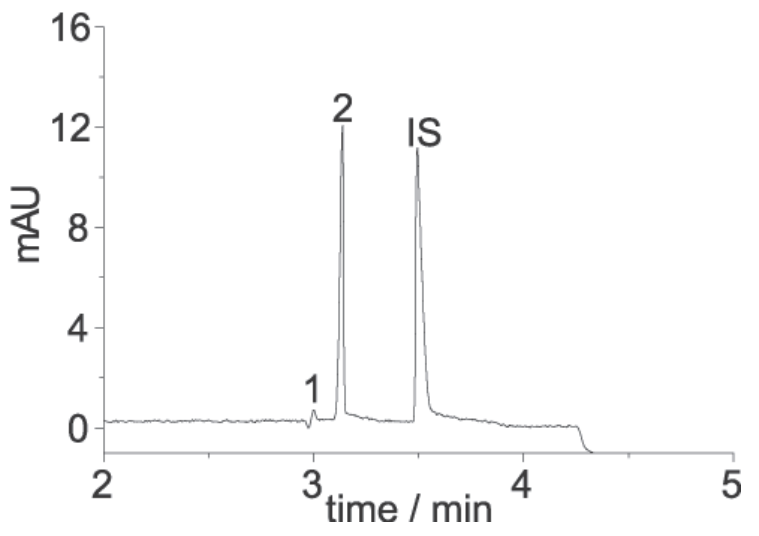

Figure 3. Electropherogram of a indinavir sulfate raw material sample. Electrophoretic conditions and peak labels as in Figure 2.

Table 5. Measured concentration of sulfate ion content in indinavir sulfate raw material

\begin{tabular}{cc}
\hline Commercial sample & ${\text { Sulfate ion } \operatorname{content}^{\mathrm{a}}(\%)}{ }^{\mathrm{a}}$ \\
\hline 1 & $13.3 \pm 0.1$ \\
3 & $13.4 \pm 0.1$ \\
& $13.5 \pm 0.1$ \\
\hline
\end{tabular}

${ }^{\text {a }}$ Average of 3 determinations.

\section{Conclusions}

A CE method has been validated for the counter ion determination in indinavir sulfate raw material. Good method performance was obtained for linearity, precision, accuracy, LOD, LOQ and specificity. Satisfactory precision data were obtained by using an internal standard. Based on the performance characteristics, the proposed methodology was shown to be eligible for the routine monitoring of sulfate in indinavir sulfate raw material.

\section{Acknowledgments}

The authors wish to acknowledge the Conselho Nacional de Desenvolvimento Científico e Tecnológico (CNPq) and the Fundação de Amparo à Pesquisa do Estado de São Paulo (FAPESP) from Brazil, for fellowships (FAPESP 02/10197-1, CNPq 301201/94-3) and financial support (FAPESP 00/04414-4 and 98/12385-2). The authors would like to acknowledge Dr. Arnaldo Alves Cardoso for allowing the use of his CE system.

\section{References}

1. Aarnoutse, R. E.; Varweij-van Wissen, C .P. W. G. M.; Underberg, W. J. M.; Kleinnijenhuis, J.; Hekster, Y. A.; Burger, D. M.; J. Chromatogr., B 2001, 764, 363. 
2. Silva, B. C.; Campos, M. M.; Pianetti, G. A.; Quim. Nova 2005, 28,54 .

3. Nishi, H.; Electrophoresis 1999, 20, 3237.

4. Baker, D. R.; Capillary Electrophoresis, Wiley: New York, 1995.

5. Altria, K. D.; Elder, D.; J. Chromatogr., A 2004, 1023, 1.

6. Haddad, P. R.; Doble, P.; J. Chromatogr., A 1999, 834, 189.

7. Munoz, R. A. A.; Richter, E. M.; De Jesus, D. P.; Lago, C. L.; Agnes, L.; J. Braz. Chem. Soc. 2004, 15, 523 (available free of charge at http://jbcs.sbq.org.br).

8. Colombara, R.; Tavares, M. F. M.; Massaro, S.; Quim. Nova 1997, 20, 512.

9. Pereira, E. A.; Tavares, M. F. M.; Jager, A. V.; Silva, C. L.; Moraes, E. P.; Lima, E. C.; Fonseca, F. N.; Tonin, F. G.; Micke, G.; Santos, M. R.; Oliveira, M. A. L.; Moraes, M. L.; Kampen, M. H.; Fujiya, N. M., J. Braz. Chem. Soc. 2003, 14, 281 (available free of charge at http://jbcs.sbq.org.br).

10. Zhou, L.; Dovletoglou, A.; J. Chromatogr., A 1997, 763, 279.

11 Fabre, H.; Blanchin, M. D.; Julien, E.; Segonds, C.; Mandrou, B.; Bosc, M.; J. Chromatogr., A 1997, 772, 265.

12. Williams, R. C.; Boucher, R. J.; J. Pharm. Biomed. Anal. 2000, 22,115 .

13 Suzuki, N.; Ishihama, Y.; Kajima, T.; Asakawa, N.; J. Chromatogr. A 1998, 829, 411.
14. Garfield, F. M.; Quality Assurance Principles for Analytical Laboratories, $2^{\text {th }}$ ed., AOAC International: Arlington, 1991.

15. Fung, Y. S.; Lau, K. M.; Talanta 1998, 45, 641.

16. Altria, K.; Chromatographia 1996, 43, 153.

17. Fabre, H.; Mesplet, N.; J. Chromatogr., A 2000, 897, 329.

18. Banchin, M. D.; Ballbaki, B.; Bosc, N.; Fabre, H.; Anal. Chim. Acta 2000, 415, 67.

19. Haddad, P.R.; Doble, P.; Macka, M.; Johns, C.; LCGC 2001, 19, 38.

20. United States Pharmacopeial Convention, US Pharmacopeia 24, Validation of Compendial Methods <1225>, Rockville, 1999.

21. International Conference on Harmonization (ICH), Validation of Analytical Procedures: Methodology, Q2B,1997.

22. Mayer, B.X.; J. Chromatogr. A 2001, 907, 21.

23. Johnson, B. D.; Howard, A.; Varsolona, R.; McCauley, J.; Ellison, D. K.; Anal. Prof. Drug Substances 1999, 26, 319

24. United States Pharmacopeial Convention; Pharmacopeial Forum, Rockville, 2000.

Received: August 11, 2005

Published on the web: January 27, 2006

FAPESP helped in meeting the publication costs of this article. 